\title{
Adoption of the Joint Stock Company in British India: History and Patterns
}

\author{
Anantdeep Singh \\ Researcher \\ University of Southern California \\ anantdeepsingh@hotmail.com
}

\begin{abstract}
The joint stock company was introduced to India in the late $17^{\text {th }}$ century but only gained widespread usage in India during the $20^{\text {th }}$ century. However, the adoption of the joint stock company was closely linked to family businesses and did not spread in a uniform manner across the population. This article will examine the spread of the joint stock company in India and look at four groups: Hindus, Muslims, non-conforming Muslims and Zoroastrians. We will suggest that the legal and business institutions of these four groups shaped their willingness to adopt the joint stock company.
\end{abstract}

\section{Introduction}

Joint stock companies are tied closely to family businesses in India. As late as 1993, of 297,000 joint stock companies in India, 294,000 were family owned. ${ }^{1}$ Joint stock companies have not replaced the Hindu joint family in India. Instead, the Hindu joint family businesses continue to be used by wealthy Hindus in conjunction with joint stock companies. This paper will examine the spread of the joint stock company in India and compare its patterns of adaptation among Hindus, Muslims, and Zoroastrians. We will suggest the following: Hindus were able to use the joint stock company to a greater extent than the Muslims due to differences in Hindu and Islamic inheritance law as well as the similarity between the Hindu joint family and the managing agency. Muslims remain underrepresented in India's business world: only one of the fifty largest business houses in India has a Muslim chairman. Recent data show that Hindus continue to dominate industry and business in India. A look at India's fifty largest business houses in 1997 shows that only one of them had a Muslim as chairman. ${ }^{2}$

The adoption of joint stock company in India was tied to the rise of the managing agency ${ }^{3}$. Joint stock companies in India were controlled by managing agencies. Managing agency contracts allowed the managing agency to have control of the joint stock company even though it did not own a majority of the shares. While Indian law prohibited banks and insurance companies from being governed by managing agencies, virtually all other private corporations were controlled by managing agencies. ${ }^{4}$ Managing agencies were in turn controlled by family businesses and were rarely owned by one person. ${ }^{5}$

Who utilized the managing agency? The vast majority of managing agencies in India were controlled by Hindus and Zoroastrians whereas the Muslim rate of ownership was minimal. Earlier studies suggest that Muslims controlled only 1. $09 \%$ of India's managing agencies. ${ }^{6}$

Let us turn to a brief discussion of the Hindu joint family businesses and their adoption of the managing agency. India in the $19^{\text {th }}$ and early $20^{\text {th }}$ century was characterized by an underdeveloped capital market. Hindu joint families used joint stock

\footnotetext{
${ }^{1}$ Dutta, 30.

2 Tripathi 2004, 340-342.

${ }^{3}$ Brimmer 561-563, Tripathi 2004.

4 Lamb 110, Tripathi 2001, 46-47.

5 Brimmer 1955, 558; Lamb 1955, 102; Tripathi 1990, 27; 2001, 43

${ }^{6}$ Nigam 1957, 104-225.
} 
companies to raise additional capital. Typically, the shares for these companies were bought by members of the same caste. How were Hindu merchants able to raise sufficient capital for this? Hindu inheritance law provides an answer. First, it allowed for the collective holding of wealth. Second, it excluded females and distant relatives from inheriting wealth.. Hindus were also familiar with the concept of a managing agency. Hindu joint families had numerous branches which were governed by a central unit.

Muslims in India were governed by Islamic inheritance law. Islamic inheritance law differed from Hindu inheritance law on two crucial counts. First, it did not allow for collective holding of wealth. Second, Islamic inheritance law included numerous heirs including women and distant relatives. This retarded the rate of capital accumulation amongst Indian Muslims.

Muslims were also hindered by relative unfamiliarity with the Hindu joint family business. The traditional means of business among India's Muslims had been the Islamic partnership. ${ }^{1}$ However the partnership differed from the Hindu joint family in two respects. First, it lacked durability. Second, Islamic partnerships could not branch out into multiple businesses as could the Hindu joint family.

A small number of Muslims did not adhere to Islamic inheritance law and utilized business institutions similar to those of the Hindus. We will refer to them as non-conforming Muslims and discuss them in greater detail below. ${ }^{2}$

\section{Joint Stock Companies in British India}

Joint stock companies were introduced in India in the 1660 s by British and Dutch merchants. However, these joint stock companies failed to gain popularity in India. They were restricted to southern India (particularly Coromandel) and failed to spread to other parts of India. It has been suggested that these companies lacked means of effective conflict resolution among shareholders. Joint stock companies were reintroduced in India in 1829. However, Indian merchants were reluctant to adopt them. The first Indian to launch a joint stock company was D. Tagore. However, few Indians followed his example and the joint stock company was largely used by Europeans in India. It was only in the $20^{\text {th }}$ century that the utilization of the joint stock company became widespread in India.

Table 1 Joint Stock Companies in India ${ }^{3}$

\begin{tabular}{ll} 
Year & JSCs in Operation in British India \\
\hline 1880 & Under 500 \\
1890 & 886 \\
1900 & 1,340 \\
1910 & 2,216 \\
1920 & 3,668 \\
1930 & 6,919 \\
1940 & 11,372 \\
1950 & 27,558 \\
\hline
\end{tabular}

Table 2: Joint Stock Companies in India from 1850 to $1950^{4}$

\begin{tabular}{ll} 
Year & Number of JSC \\
\hline 1851 & 2 \\
1852 & 4
\end{tabular}

\footnotetext{
${ }^{1}$ The common forms of Islamic partnership include the mudaraba, mufawada, and 'inan. See Udovitch for a further discussion of Islamic partnerships.

2 These Muslims belonged to the Khoja, Bohra, and Memon castes.

${ }^{3}$ Rungta pg 47.

${ }^{4}$ Rungta, 47.
} 


\begin{tabular}{ll}
1853 & 7 \\
1854 & 11 \\
1855 & 11 \\
1856 & 12 \\
1857 & 16 \\
1858 & 22 \\
1859 & 38 \\
1860 & 48 \\
\hline
\end{tabular}

In 1851, twenty two years after the founding of the first joint stock company in India, only two joint stock companies were in operation. The Act of 1857 also failed to stimulate the growth of joint stock companies. What explains the tepid growth of joint stock companies in India?

First joint stock companies could only get corporate status through an act of the British Parliament or the Indian Legislature. Second, joint stock companies were seen as partnerships. Third, the liability of every shareholder was unlimited. The Act of 1857 remedied many of these defects but joint stock companies still grew slowly in India.

India suffered from a dearth of both capital and entrepreneurship. Organized capital markets did not exist in India. Banks typically served the needs of only Europeans. On the other hand, Indian moneylenders charged exorbitant interest rates. The peasantry and working class's incomes were insufficient to generate the requisite capital for industrial ventures.

\section{Managing Agencies in British India}

Indian merchants were also reluctant to invest in industrial ventures. Most chose to remain in retail, trade and moneylending. Managing agencies bridged the gap and offered a solution to the lack of entrepreneurs and lack of capital. How did managing agencies bridge the gap? How did managing agencies operate? Managing agents assessed the costs necessary for a particular enterprise. They also assessed the size of the market. Managing agents then registered the company and selected the board of directors. The agents would sell shares but through a managing agency contract, retain control of the company. This process was repeated numerous times and eventually managing agencies controlled numerous companies. This allowed managing agencies to overcome the dearth of capital.

Managing agencies became extensions of the joint family. The members of the managing agency were members of the same family. Highest authority was given to the eldest male. The shares were bought by members of the same family or social network. A single family retained control of multiple companies through the managing agency contract. Funds from one company would be used to launch other companies. Indian banks were also more willing to lend to companies which were managed by managing agencies.

\section{A Comparison of the Spread of the Managing Agency and Joint Stock Company}

Which groups in India adopted the managing agency? The adoption of the managing agency took place with relative ease among Hindu merchant castes. First, these castes could raise money through their social networks. Second, the managing agency model matched the Hindu joint family business model in that a central unit managed numerous branches.

The Muslims of India were disadvantaged on both counts. First, Muslims experienced fragmentation of their estates due to Islamic inheritance law. Second, the Islamic partnership differed radically from the managing agency and the joint stock company so Muslim businessmen were unable to make the transition.

A look at table 3 shows us the presence of Hindus and Zoroastrians the absence of Muslims. Table 3 shows us the results of three different studies. The first list shows the largest industrial houses in India after independence was the result of a government study, the Monopolies Inquiry Commission. Of the 37 houses, 34 are controlled by Hindu business families, 
two by Zoroastrians, and on by a Jewish businessman. ${ }^{1}$ The second list is R. K. Hazari's The Structure of the Corporate Private Sector. Hazari's list includes business houses of various sizes and is adjusted for region, caste, and assets. Of the 17 business houses in Hazari's list, 15 are controlled by Hindus and the remaining two by Zoroastrians. Sharma's Entrepreneurial Change in Indian Industry which lists India's 58 largest business houses in 1969. Of these 58, 55 are controlled by Hindus and 3 by Zoroastrians. Sharma's list also has no Muslims as owners of business houses.

Table 3: India's largest companies and business houses

\begin{tabular}{llll} 
Community & $\begin{array}{l}\text { Monopolies Inquiry } \\
\text { Commission }\end{array}$ & R. K. Hazari & Sharma \\
\hline Hindu & 34 & 15 & 55 \\
Zoroastrian & 2 & 2 & 3 \\
Muslim & 0 & 0 & 0 \\
& & & \\
\hline
\end{tabular}

What conclusions may we draw from the table above? First, the bulk of business houses in India were controlled by the Hindus. Second, the Zoroastrians controlled a proportion of business houses significantly greater than their population. ${ }^{2}$ Third, Muslims despite possessing approximately $12 \%$ of India's population did not own a single business house which ranked among the largest.

What accounts for the Zoroastrian prominence in business? Bagchi has suggested that the Zoroastrian success stems from two factors: they were located in the commercial hub of Bombay and they served as middlemen of the British. ${ }^{3}$ Bagchi's assertion is questionable on two points. First, other groups that lived in Bombay did not achieve the same level of success. Second, why were the Zoroastrians chosen as "middlemen" and how did this necessarily imply success in industry? Others have suggested that the Zoroastrian success is due to their Westernization and greater level of education. However, other minorities such as Brahmins also possessed knowledge of the English language but did not achieve the same level of success. The commercial success of the Zoroastrians may be attributed to confluence of factors including inheritance laws, communal institutions, and their ability to raise capital. ${ }^{4}$

Let us turn to a brief discussion of non-conforming Muslims. This group followed Islam but used Hindu inheritance law and business institutions. Like the Zoroastrians, their influence is significantly greater than the proportion of their population. A significant portion of the non-conforming Muslim population migrated to Pakistan after the partition of British India in 1947. 5 We can see the significant role played by the non-conforming Muslims from the table 4 below.

Table 4

Industrial Investment in Pakistan in $1960^{6}$

\begin{tabular}{lll} 
Community & $\begin{array}{l}\text { Proportion of Industrial } \\
\text { Investment }\end{array}$ & Proportion of Population \\
\hline Memon & $27 \%$ & $0.3 \%$ \\
Bohra & $5 \%$ & $0.04 \%$ \\
Khoja & $11 \%$ & $0.14 \%$ \\
All Other Muslims & $57 \%$ & $99.52 \%$
\end{tabular}

\footnotetext{
1 Timberg 17-20.

2 The Zoroastrian population was approximately 100,000 out of a population of over 300 million in India.

3 Bagchi, Private Investment in India.

4 Further study is needed on the Zoroastrians. See Desai 1968; White 1987

${ }^{5}$ See Levin 1974 and Papanek 1962.

${ }^{6}$ Papanek 1962
} 
Not only did non-conforming Muslims possess a significant proportion of Pakistan's business houses, they also contributed to a disproportionately large segment of industrial investment. Since the non-conforming Muslims possessed the same inheritance law and business institutions of the Hindus, we can see that they were able to raise capital relatively easily and also adopt to the managing agency system.

Let us discuss the remaining population of Indian Muslims. First, the Indian Muslims could not raise capital as easily as Hindus. While Hindu inheritance laws encourage the collective holding of wealth and discourage the fragmentation of estates, Islamic inheritance law includes a greater number of heirs and divides estates with every generation. A wealthy Muslim family was likely to experience division of its estate whereas a Hindu family would not experience such division. Second, Hindu entrepreneurs possessed caste networks whereas Indian Muslims did not have access to such networks. ${ }^{1}$ Muslim attempts to raise capital were hindered. In 1889, Muslim businessmen established Koilpatti Mills in south India. However, this mill failed from a lack of sufficient funds. In 1895, Muslim businessmen attempted to launch the Petai Sugar Refining Company. This was transformed into a joint stock company with limited liability. However, the owners could not raise sufficient capital and this venture was sold to Hindu businessmen. ${ }^{2}$

Muslim businessmen also suffered from a lack of experience in running managing agencies. A Hindu family business was controlled by one central unit whereas a Muslim business operation was a partnership and lacked branches. A look at case studies will reveal how Hindu joint family businesses functioned vis-à-vis partnerships.

\section{Case Studies}

Case Study 1: The Mafatlal family

Mafatlal began his career in 1886 and worked menial jobs and as a peddler. However he saved his capital and in 1905 lauched the Shorrock Spinning and Manufacturing Company. The share for this joint stock company were bought by members of his caste. He used a managing agency to control the company since he did not possess the majority of the shares. Mafatlal expanded his business to include more mills, cotton ginneries, and also entered the field of business. His sons and grandsons controlled the businesses through managing agency contracts. ${ }^{3}$

Analysis: The Mafatlal family utilized the Hindu joint family business very effectively. They were able to include sons and grandsons as managing agents of their business empire. Second, they also were able to tap into caste networks to raise capital for launching their joint stock company. Had the Mafatlals not been familiar with the Hindu joint family business, they might not have been able to use their caste networks or know how to utilize the managing agency.

\section{Case Study 2: The Birlas}

The Birlas were a prominent moneylending family. They owned branches throughout India. The Birlas expanded their business to precious metals, cotton, and trade in the $19^{\text {th }}$ century. They launched their first cotton mill in 1916 and their first joint stock company in 1918. The Birlas used managing agency contracts to control their business and eventually had over 50 joint stock companies in areas as diverse as cotton, manufacturing and retail.

Analysis: The Birlas relied heavily on the Hindu joint stock company business. They used its structure to expand throughout India and into diverse areas. They were able to effectively use managing agency contracts to control businesses while not possessing a majority of the shares in these businesses.

\section{Conclusion}

Our discussion has shed light on the performance of different groups in British India: Hindus, Muslims, Zoroastrians and non-conforming Muslims. We saw that the Hindus and non-conforming Muslims were advantaged by the use of the Hindu joint family business whereas the Zoroastrians benefitted from a confluence of factors. On the other hand, Islamic

\footnotetext{
1 See Ahmad 1991, Leonard 1981.

2 Tripathi, 1984 228-236.

3 Hazari 1966, 207-208; Tripathi 1990, 105-114
} 
inheritance law fragmented estates. The Islamic partnership lacked the ability to branch out and this hindered the success of Muslim businessmen.

\section{Sources}

Ahmad, N. (1991) Muslim Separatism in British India Lahore, Ferozsons Ltd.

Bagchi, Amiya Kumar (1976) Private Investment in India: 1900-1939 Cambridge, Cambridge University Press

Brimmer, Andrews F. (1955) "The Setting of Entrepreneurship in India" Quarterly Journal of Economics, 119 (4): 553-576

Desai, Ashok V. (1968) "Origins of Parsi Enterprise" Indian Economic and Social History Review 5 (4): 307-317

Dutta, Sudipt (1997) Family Business in India New Delhi, Response Books

Government of India (1955) Progress of Joint Stock Companies in India Delhi, Sunlight Printers

Hazari R. K. (1966) The Structure of the Corporate Private Sector: A Study of Concentration, Ownership, and Control, London, Asia Publishing House

Lamb, Helen B. (1955) "The Indian Business Communities and The Evolution of an Industrial Class" Pacific Affairs, 18 (2): $101-116$

Leonard, Karen (1981) "Banking Firms in Nineteenth-Century Hyderabad Politics," Modern Asian Studies 15(2): 177-201

Levin, Sergey (1974) "The Upper Bourgeoisie from the Muslim Commercial Community of Memons in Pakistan, 19471971," Asian Survey, 14(3), 231-43

Nigam, R. K. (1957) Managing Agencies in India, Delhi, Ministry of Commerce, Government of India

Papanek, Gustav F. (1962) "The Development of Entrepreneurship," American Economic Review 52(2):46-58

Rungta, R. S. (1970) The Rise of Business Corporations in India, 1850-1900, Cambridge, Cambridge University Press

Sharma, R. A. (1980) Entrepreneurial Change in Indian Industry New Delhi, Sterling Publishers

Timberg, Thomas A. (1969) Industrial Entrepreneurship Among the Trading Communities of India: How the Pattern Differs Cambridge Massachusetts, Development Advisory Committee

Tripathi, D. (1984) Business Communities of India: A Historical Perspective, New Delhi, Manohar

Tripathi, D. (2004) Oxford History of Indian Business, New Delhi, Oxford University Press

Udovitch, Abraham A. (1970) Partnership and Profit in Medieval Islam Princeton, Princeton University Press

White, D. L. (1987) "Parsis in the Commercial World of Western India, 1700-1750" Indian Economic and Social History Review 24(2):183-203 